\title{
Adoptive Transfer of Suppression of Arthritis in the Mouse Model of Collagen-induced Arthritis \\ Evidence for a Type II Collagen-specific Suppressor $\mathbf{T}$ Cell
}

Thomas F. Kresina and Roland W. Moskowitz

Division of Rheumatology, Departments of Medicine and Pathology, School of Medicine,

Case Western Reserve University, Cleveland, Ohio 44106

\begin{abstract}
This study details the suppressive mechanism involved in the antigen-specific suppression of collagen-induced arthritis. Intravenous injection of $500 \mu \mathrm{g}$ of soluble native type II collagen $3 \mathrm{~d}$ before immunization with native type II collagen emulsified in complete Freund's adjuvant resulted in animals with decreased in vitro cellular and humoral immune response to native and denatured type II collagen compared with control groups. Control groups were composed of animals preinoculated with saline and type I collagen and established the antigen-specific nature of the observed suppression. Mice with reduced immune responses to type II collagen also were observed to portray little or no erythema and edema associated with collageninduced arthritis. Adoptive transfer experiments established the requirement of $T$ cells for the suppression of collageninduced arthritis. Analysis of the phenotype of responding splenic cells in chronic immunotherapeutically suppressed mice in vitro revealed that responding cells were $\mathrm{Ly1}^{-} 2^{+}$(suppressor/ cytotoxic) $T$ cells. On the other hand, the cellular phenotype of $T$ cells responding to type II collagen in nonsuppressed collagen-induced arthritic mice was $\mathrm{Ly1}^{+} 2^{-}$(helper/inducer $\mathrm{T}$ cells). The data indicate that type II collagen-specific $T$ cells are generated on intravenous inoculation of soluble native type II collagen. These cells are observed in type II collagenimmune animals, which are nonarthritic and portray reduced humoral and in vitro cellular immune response to type II collagen. This study suggests that specific suppression of immune responses to type II collagen by $\mathbf{T}$-suppressor cells can be immunotherapeutic in certain forms of arthritis.
\end{abstract}

\section{Introduction}

A polyarthritis can be induced in specific strains of rats (1) or mice (2) by immunization with native homologous or heterologous type II collagen preparations. This animal model of proliferative synovitis is characterized by the development of both cellular and humoral immune responses to type II collagen $(3,4)$. Collagen-induced arthritis $(\mathrm{CIA})^{1}$ can be adoptively transferred to naive rats by sensitized spleen cells (5)

\footnotetext{
Address correspondence to Dr. Kresina.

Received for publication 7 August 1984 and in revised form 6 February 1985.

1. Abbreviations used in this paper: CFA, complete Freund's adjuvant; CIA, collagen-induced arthritis; SI, stimulation index.
}

J. Clin. Invest.

(C) The American Society for Clinical Investigation, Inc. 0021-9738/85/06/1990/09\$\$1.00

Volume 75, June 1985, 1990-1998 and passively transferred by immunoglobulin $G$ specific for type II collagen (6). These observations are consistent with the contention that CIA results from immunologic hypersensitivity to type II collagen. Recent studies have noted that the immune responses to collagen as well as arthritic responses in rats with CIA can be modulated by free collagen and anti-collagen antiserum (7). In addition, administration of collagen-coupled spleen cells (8), native type II collagen (9), or specific constituent $\mathrm{CNBr}$ peptides (10) before immunization with type II collagen results in the antigen specific suppression of CIA in rats. Rats administered collagen-coupled erythrocytes have also been utilized as splenic cell donors in studies showing the adoptive transfer of antigen-specific suppression of collagen arthritis (11). However, the cell(s) responsible for this antigen-specific suppression have not been determined. The present study extends the previous observations of antigen-specific suppression of CIA to the murine model of CIA. In addition, adoptive transfer experiments were performed to establish the cellular subpopulation necessary for immunotherapeutic suppression of arthritis. The present data indicate that Thy $1^{+} \mathrm{Lyl}^{-} 2^{+}$type II collagen-specific spleen cells ( $T$ cells) are generated on intravenous preinoculation with native heterologous type II collagen. Furthermore, these $\mathrm{T}$ suppressor cells depress in vitro cell-mediated immune responses to type II collagen and serum anti-type II collagen antibody titers observed in mice with CIA as well as the concomitant erythema and edema of synovitis observed in murine CIA.

\section{Methods}

Mice. Female DBA/1J mice (6-12 wk of age) were purchased from Jackson Laboratory (Bar Harbor, ME).

Collagen purification. Native interstitial type I and type II collagens were isolated from pepsin digests of tissues rich in the particular isotype of collagen as described previously (12). In brief, preparations of type I collagen were isolated from rabbit dermis and preparations of type II collagen were isolated from rabbit xyphoid process. Solubilized collagen was purified by differential salt precipitation from neutral salt or acid solutions (13). Collagen preparations were further purified by native state carboxymethylcellulose chromatography (for native type I collagen) and diethyleaminoethane cellulose chromatography (for native type II collagen) utilizing previouslý detailed conditions $(14,15)$. Under these conditions, native interstitial collagen can be totally resolved from basement membranes or other related collagenous components as well as proteoglycan moieties. Assessment of purity was performed by molecule sieve, ion exchange chromatography, and 5\% sodium dodecyl sulfate (SDS)-polyacrylamide gel electrophoresis. In addition, the type II collagen preparation at concentrations of $>2 \mathrm{mg} / \mathrm{ml}$ was routinely assayed for uronic acid content. No uronic acid was detected with the limits of detection at $1 \mu \mathrm{g}$ of uronic acid. Denaturation of the native collagen preparation was achieved by incubation at $60^{\circ} \mathrm{C}$ for $\mathbf{4 5} \mathrm{min}$ just before utilization.

Collagen-induced arthritis. Murine CIA was induced by a modified 
method of Courtenay et al. (2). In brief, $100 \mu \mathrm{g}$ of purified rabbit type II collagen emulsified in complete Freund's adjuvant (CFA) was injected intradermally at the base of the tail on day 0 . A second identical injection of antigen emulsified in CFA was administered intraperitoneally on day 14. Mice were observed for onset of arthritis which, in general, occurred 4 wk after the initial injection. Animals were monitored daily for arthritis until they were killed. Preinoculation of antigen for suppression studies occurred $3 \mathrm{~d}$ before day 0 . A single intravenous injection consisting of $500 \mu \mathrm{g}$ of native collagen (type I or type II) in $0.2 \mathrm{ml}$ of isotonic saline was administered.

In parallel suppression studies, single intravenous injection of ${ }^{125} \mathrm{I}$ radiolabeled type II collagen (chloramine-T method [16]) was administered to establish the amount of antigen carry-over in the single cell suspensions during adoptive transfer. $100 \mu \mathrm{g}$ of type II collagen with a specific activity of $2,200 \mathrm{cpm} / \mathrm{ng}$ was injected intravenously in 0.2 $\mathrm{ml}$ saline $3 \mathrm{~d}$ before adoptive transfer. At sacrifice, both whole spleen and subsequent single cell suspensions were counted in a Beckman gamma counter model 5500 (Beckman Instruments, Inc., Fullerton, CA).

Pathology scoring. Paws were individually scored for arthritis on a scale of 1-5 based on the amount of erythema and enlargement, distortion, or limitation of movement of the joints. Scoring ranged from 1, corresponding to mild erythema of the foot pad, to 5 , corresponding to ankylosed and deformed joints with diffuse edema. In addition, the number of enlarged terminal digits on inflamed paws was recorded. The pathology scores presently tabulated represent the values obtained when the animals were killed, $50 \mathrm{~d}$ after the initial immunization with type II collagen/CFA.

Adoptive transfer. Control mice and collagen-preinoculated mice were killed $3 \mathrm{~d}$ after intravenous injection, and spleens from each group were removed, pooled, and minced into single cell suspensions. The cells were exposed to a solution containing $0.15 \mathrm{M} \mathrm{NH}_{4} \mathrm{Cl}, 0.017$ $\mathrm{M}$ Tris, $\mathrm{pH} 7.2$, for $5 \mathrm{~min}$ at $0^{\circ} \mathrm{C}$ to lyse erythrocytes (12). The resulting cellular suspension was analyzed for cell viability by trypan blue exclusion ( $>90 \%$ viable in all cases), and $1 \times 10^{7}$ cells were resuspended in $0.2 \mathrm{ml}$ of isotonic saline for intravenous injection. Cells were adoptively transferred to naive animals via the tail vein $4 \mathrm{~d}$ prior to immunization with collagen. For cell depletion studies, cell suspensions were treated with monoclonal anti-Thy 1.2 (Cedarlane Laboratories Ltd., Hornby, Ontario, Canada) and low-tox-m rabbit complement (Cedarlane Laboratories Limited) for $30 \mathrm{~min}$ at $37^{\circ} \mathrm{C}$ to lyse $\mathrm{T}$ cells. Subsequent to this procedure, cells were analyzed for cell viability and adoptively transferred to naive mice as described above.

Cell-mediated immune responses. In vitro cell-mediated immune responses were determined for spleen cell populations utilizing native and denatured type II collagen as antigens as previously described (12, 17). In brief, when the animals were killed, spleens were removed and individually minced into single cell suspensions, and erythrocytes were lysed. The resulting cellular suspension was analyzed for cell viability by trypan blue exclusion ( $>95 \%$ viable in all cases) and $2 \times 10^{5}$ viable cells were aliquoted in microwells for culture in $200 \mu \mathrm{l}$ of RPMI 1640 media supplemented with $10 \%$ heat-inactivated fetal calf serum (M. A. Bioproducts, Walkersville, MD), $2 \mathrm{mM}$ Hepes, and penicillinstreptomycin. The cultures were incubated at $37^{\circ} \mathrm{C}$ at $5 \% \mathrm{CO}_{2}$. Antigens diluted in normal saline, $\mathrm{pH} 7.5$, to various concentrations and native or denatured type II collagen $(50,5$, and $0.5 \mu \mathrm{g} / \mathrm{ml})$ were added $(20 \mu \mathrm{l})$ at initiation of the cultures. Individual cultures incubated with a specific concentration of antigen were performed in triplicate. Diluent cultures, receiving $20 \mu$ of saline were performed a minimum of six times on individual microtiter plates. Analysis of the phenotype of the cellular populations responding to type II collagen in vitro were performed by cellular depletion studies utilizing monoclonal anti-Thy 1.2, monoclonal anti-mouse Lyl (Becton Dickinson Monoclonal Center, Mountain View, CA) and monoclonal anti-mouse Ly2 (Becton, Dickinson Monoclonal Center). Splenic single cell suspensions were incubated for $30 \mathrm{~min}$ at $37^{\circ} \mathrm{C}$ with individual monoclonal antibodies and incubated with low tox-m rabbit complement for $30 \mathrm{~min}$ at $37^{\circ} \mathrm{C}$ Cellular suspensions were analyzed for cellular viability by trypan blue exclusion and plated in microwells for analysis of in vitro cellular responses to type II collagen. Cell suspensions were retreated with the appropriate antisera and complement to insure maximum specific cytotoxicity. The cultures were incubated for a period of $4 \mathrm{~d}$ with individual daily 24-h pulses of $0.5 \mu \mathrm{Ci}\left[{ }^{3} \mathrm{H}\right]$ thymidine. Cultures were harvested daily after pulsing in a mine-mash cell harvester (M. A. Bioproducts) and counted in a Packard Tri-carb model 3330 liquid scintillation spectrometer (Packard Instrument Co., Inc., Downers Grove, IL). Data is expressed as a stimulation index (SI) defined as: mean cpm of incorporated antigen-stimulated culture/mean cpm of incorporated diluent culture. Criteria for significant immune responses were $\mathrm{SI} \geq 2.0$ and in the comparison of diluent vs. antigen-incubated cultures $P \leq 0.05$.

Radioimmunoassay for anti-type II collagen antibodies. Serum anti-collagen antibodies were determined by utilizing a solid-phase radioimmunoassay (18) as described previously (19). In brief, polyvinyl microtiter plates were incubated with $20 \mu \mathrm{l}$ of a neutral $\mathrm{pH}$ sodium bicarbonate solution containing the native or denatured type II collagen $(1 \mathrm{mg} / \mathrm{ml})$ for $24 \mathrm{~h}$ at $4^{\circ} \mathrm{C}$. Subsequent to the adherence of antigen to the wells, the plates were washed with a bicarbonate buffer, $\mathrm{pH} 7.5$, and filled with a solution of $2 \%$ BSA (bovine serum albumin) in bicarbonate for $24 \mathrm{~h}$ at $4^{\circ} \mathrm{C}$. This procedure reduced the nonspecific background binding by blocking remaining sites of adherence in the wells. In parallel wells, by utilizing nanogram quantities of radiolabeled collagens $(2,200-3,000 \mathrm{cpm} / \mathrm{ng})$ added to these collagen solutions, it was determined that $\sim 0.1 \%$ of the quantity of the collagen added to the wells irreversibly adhered to the plates under these conditions. Subsequent to this incubation, $20 \mu \mathrm{l}$ of bicarbonate buffer and $20 \mu \mathrm{l}$ of serum dilution $(1: 10,1: 50,1: 100,1: 1,000,1: 5,000,1: 10,000)$ were incubated in the wells for $18 \mathrm{~h}$ at $4^{\circ} \mathrm{C}$. The wells were washed thoroughly with bicarbonate buffer and filled with $50 \mu \mathrm{l}(125 \mathrm{ng})$ of ${ }^{125}$ I-labeled goat anti-mouse IgG (Cappel Laboratories, Cochranville, PA). This reagent was incubated in the wells of the plates for $12 \mathrm{~h}$ at $4^{\circ} \mathrm{C}$. The wells were washed 12 times with bicarbonate buffer, dried by air, and counted in a Beckman 5500 gamma counter. Quantitation of the bound antibody was determined by utilization of binding data derived from samples containing known quantities of specifically purified murine anti-type II collagen antibodies. Anti-type II collagen antibodies were isolated by elution from type II collagen-coupled Sepharose 4B (cyanogen bromide method) with a solution of $0.1 \mathrm{M}$ glycine- $\mathrm{HCl}$ pH 2.5 (20). Antibody concentration was calculated by determination of optical density at $280 \mathrm{~nm}$ utilizing the molar extinction coefficient for immunoglobulin molecules, a value of 14,830 .

Statistics. $P$ values for the antibody concentration and cell-mediated immune responses were determined by utilizing the Student $t$ test. $P$ values for the inflammation pathology scores were determined utilizing a Mann-Whitney test.

\section{Results}

\section{Suppression of CIA in the mouse}

Pathology. Initial experiments were performed to detail the suppression of CIA in the murine model of arthritis. Three groups of eight DBA/1J mice were preinoculated with $0.2 \mathrm{ml}$ of phosphate-buffered saline, $500 \mu \mathrm{g}$ of native type I collagen, or $500 \mu \mathrm{g}$ of native type II collagen in $0.2 \mathrm{ml}$ of phosphatebuffered saline and were subsequently immunized with type II collagen. The results obtained for the arthritis pathology score for these animals are summarized in Table I. Groups 1 and 2 (preinoculated with saline and type I collagen, respectively) were observed to have a high incidence of arthritis. With regard to gross pathology scoring, inflammation (erythema and edema) was most prominent in the hind paws with the left, on the average, more severe than the right. The corollary was observed for the forepaws with the right paw displaying a more severe, gross pathological condition, on the average, than the 
Table I. Suppression of CIA in the Mouse by Preinoculation of Native Type II Collagen: Arthritis Pathology Score*

\begin{tabular}{|c|c|c|c|c|c|c|c|}
\hline \multirow[b]{3}{*}{ Group } & \multirow[b]{3}{*}{ Preinoculation (i.v.) $\ddagger$} & \multirow[b]{3}{*}{$\begin{array}{l}\text { Incidence of } \\
\text { inflammation§ }\end{array}$} & \multicolumn{4}{|c|}{ Inflammation" } & \multirow[b]{3}{*}{$\begin{array}{l}\text { Terminal } \\
\text { digits involvedf }\end{array}$} \\
\hline & & & \multicolumn{2}{|c|}{ Hind paw } & \multicolumn{2}{|c|}{ Forepaw } & \\
\hline & & & Left & Right & Left & Right & \\
\hline 1 & Saline & $8 / 8$ & 2.1 & 1.5 & 0.9 & 1.3 & 1.1 \\
\hline 2 & $500 \mu \mathrm{g}$ of native type I collagen** & $8 / 8$ & 2.5 & 2.0 & 1.3 & 1.5 & 1.3 \\
\hline 3 & $500 \mu \mathrm{g}$ of native type II collagen** & $0 / 7$ & 0.4 & 0.0 & 0.1 & 0.0 & 0.0 \\
\hline
\end{tabular}

* Animal paws individually scored for arthritis on a scale of 0-5 based on the amount of erythema and edema, distortion, or ankylosis of the joint. $¥$ Mice administered intravenous injection $3 \mathrm{~d}$ before immunization with $100 \mu \mathrm{g}$ of native type II collagen emulsified in CFA. Day of initial immunization of collagen was designated day 0 . § Number of animals with a recorded pathology score $>1$ by day 50 divided by the total number of mice per group at day 50. "Average pathology score for the individual paw of each mouse in the designated group. A statistical analysis of the inflammation pathology scores revealed no statistical difference (NS) for values obtained for groups 1 and 2 . However, comparison of group 1 vs. 3 and group 2 vs. 3 revealed a statistically significant reduction of inflammation in group 3 at the following levels. Group 1 vs. 3, hind paw: left, $P<0.002$; right, $P<0.006$; forepaw: left, $P=\mathrm{NS}$; right, $P=0.05$. Group 2 vs. 3 , hind paw: left, $P=0.0006$; right, $P$ $<0.006$; forepaw: left, $P=0.0005$; right, $P=0.008$. T Average number of enlarged terminal digits per inflamed (score $\geq 1)$ paw. ${ }^{* *}$ Neutral salt-soluble collagen isolated and purified as described in the text.

left paw. For all inflamed paws at least one terminal digit was observed to be involved. The gross pathology score and inflammation incidence for group 3 (preinoculated with native type II collagen) were substantially reduced with regard to the pathology score. The $P$ values listed as in Table I ranged from 0.05 to 0.0005 . Animals in this group displayed only mild erythema on the left fore- or hind paws with no swelling of the terminal digits. None of the animals in this group was observed to display enlargement or distortion of limitation of movement of the joints.
Immune response to native and denatured type II collagen. The cell-mediated and humoral immune responses to type II collagen for the animals comprising the arthritic groups (salineand type I collagen-preinoculated, groups 1 and 2, respectively) and the nonarthritic group (native type II collagen-preinoculated, group 3) are summarized in Table II. As shown in Table II, cell-mediated immune responses directed to native type II collagen (recorded as an SI) were observed in the arthritic group (SI: group 1, 2.7 \pm 1.4 ; group 2, 4.3 \pm 0.7 ). Treatment of these cultures with monoclonal anti-Thy 1.2 and complement

Table II. Suppression of CIA in the Mouse by Preinoculation of Native Type II Collagen: Immune Response to Type II Collagen

\begin{tabular}{|c|c|c|c|c|c|c|}
\hline \multirow[b]{3}{*}{ Group* } & \multicolumn{6}{|c|}{ Immune response } \\
\hline & \multicolumn{4}{|c|}{ Cell-mediated $\ddagger$ type II collagen } & & \\
\hline & Diluent & $\alpha$ Thy $1+C^{\prime}$ & Diluent & $\alpha$ Thy $1+\mathrm{C}^{\prime}$ & Native & Denatured \\
\hline & & & & & $m g / m l$ & $m g / m l$ \\
\hline 1 & $2.7 \pm 1.4^{\prime \prime}$ & $0.9 \pm 0.5$ & $1.2 \pm 1.0$ & $0.6 \pm 0.6$ & $5.6 \pm 1.1 \pi$ & $5.0 \pm 1.1$ \\
\hline 2 & $4.3 \pm 0.7$ & $0.2 \pm 0.1$ & $2.5 \pm 1.6$ & $0.7 \pm 0.8$ & $6.1 \pm 0.7$ & $5.4 \pm 0.4$ \\
\hline 3 & $2.1 \pm 0.7$ & $0.9 \pm 0.7$ & $1.4 \pm 0.9$ & $0.4 \pm 0.2$ & $0.6 \pm 0.04$ & $1.9 \pm 0.3$ \\
\hline
\end{tabular}

\footnotetext{
* Animals preinoculated as described in Table I. $\ddagger$ In vitro cell-mediated immune response of splenic cells derived from the designated groups. Before incubation with native or denatured type II collagen, single cell preparations were incubated with saline and complement (diluent) or anti-Thy 1.2 and complement $(\alpha$ Thy $1+C)$. The latter procedure was utilized to remove functional T cells from the preparations. On the average, $36 \%$ of the cells were determined by trypan blue exclusion to be lysed utilizing this methodology. § Antibody concentrations determined using a solid-phase radioimmunoassay. "Values presented as a stimulation index (defined in text) \pm standard deviation. Antigen incubated wells were performed in triplicate while saline incubated wells were replicated minimally six times. The $\left[{ }^{3} \mathrm{H}\right]$ thymidine incorporation levels of the nonstimulated cultures for the groups were: group 1, 2,183 \pm 771 ; group 2, 2,532 $\pm 1,237$; group 3, 2,312 $\pm 1,515$. Statistical analysis of the in vitro cell-mediated immune responses directed toward native and denatured type II collagen were as follows: native type II collagengroup 1, diluent vs. $\alpha$ Thy $1.2+C^{\prime}, P<0.01$; group 2 , diluent vs. $\alpha$ Thy $1.2+C^{\prime}, P<0.001$; group 3 , diluent vs. $\alpha$ Thy $1.2+C^{\prime}, P<0.01$; denatured type II collagen-group 1, diluent vs. $\alpha$ Thy $1.2+C^{\prime}$, NS; group 2: diluent vs. $\alpha$ Thy $1.2+$ C, NS; group 3: diluent vs. $\alpha$ Thy 1.2 $+\mathrm{C}, P<0.05$. Statistical analysis of the in vitro cell-mediated immune responses for type II collagen was group 1 vs. 3, native and denatured type II collagen, NS; group 2 vs. 3, native type II collagen, $P<0.05$, and denatured collagen, NS. II Concentration of antibody determined by utilizing binding data from samples of known concentration of specifically purified anti-type II collagen antibodies (see text). The observed reduction in concentrations of anti-collagen antibodies to native or denatured type II collagen observed in CIA-suppressed mice is statistically significant at $P<0.05$ and $P<0.02$, respectively.
} 
resulted in the statistically significant reduction of these responses to nonstimulatory levels (SI: group 1, $0.9 \pm 0.5 P$ $<0.01$; group $2,0.2 \pm 0.1 P<0.001$ ) indicating cellular responses were of $\mathrm{T}$ cell origin. However, denatured type II collagen was marginally blastogenic in group 2 (SI: $2.5 \pm 1.6$ ), and this response was reduced to $0.7 \pm 0.8$ on treatment with anti-Thy 1.2 and complement. These data indicate only marginal cell-mediated immune responses to the $\alpha 1$ (II) polypeptide at the concentrations utilized. In vitro cell-mediated immune responses to native or denatured type II collagen were observed at a comparatively reduced level in the type II collagenpreinoculated group. These reduced responses were also abrogated by treatment with anti-Thy 1.2 and complement $(P$ $<0.01$ native type II collagen; $P<0.05$ denatured type II collagen) indicating responses of $\mathrm{T}$ cell origin. The animals of the type II collagen-preinoculated group, as noted in Table I, were observed not to present the fore- and hind paw erythema and edema associated with collagen-induced arthritis. In addition, this group of animals was observed to have a significant decrease $(P<0.05)$ in the cell-mediated response for native type II collagen compared only to the type I collagen-inoculated group (group 2).

The humoral immune response to native and denatured collagen is also summarized in Table II. In groups 1 and 2, which displayed a $100 \%$ incidence of arthritis, a relatively high concentration of serum antibodies to both native and denatured collagen was observed. The animals in group 3 (nonarthritic) display reduced concentrations of serum antibodies to both native and denatured collagens, $P<0.05$ and $<0.02$, respectively.

The results of the pathology score and immune response to type II collagen taken together indicate that, in the murine model of CIA arthritis, both antigen-specific cell-mediated and humoral immune responses to type II collagen are observed.
Preinoculation with native type I collagen does not modulate the pathological condition observed or the immune response to type II collagen. However, preinoculation of $\mathrm{DBA} / 1 \mathrm{~J}$ mice with native type II collagen results in virtually no observable inflammation with reduced cell-mediated and humoral immune responses to type II collagen.

\section{Adoptive transfer of CIA}

Gross pathology. The observation of antigen-specific suppression of CIA in the mouse model of CIA led to further experiments that were designed to establish the cell(s) lineage capable of immunosuppression of CIA. Table III details the splenic cells and subpopulations utilized in adoptive transfer experiments. 10 million splenic cells from saline, native type $I$ or native type II collagen-preinoculated mice, (groups 1, 2, and 3, respectively, in Table III) were adoptively transferred via the tail vein to naive mice and subsequently immunized with type II collagen. As shown in Table III, groups 1 and 2 displayed a high incidence of inflammation (group 1, 10 of 11 animals or $91 \%$ incidence of inflammation; group 2, eight of eight animals or $100 \%$ incidence of inflammation) with extensive involvement of the left hind paw and right forepaw as indicated by the inflammation pathology score. In addition, at least one terminal digit was enlarged in the inflamed paw. However, the animals that received cells from mice preinoculated with native type II collagen (Table III, group 3) were observed to have both a lower incidence of inflammation (5 of 16 animals or $31 \%$ ) and a statistically significant lower inflammation pathology score. For group 1 vs. $3, P$ values for hind paw left/right and forepaw left/right pathology scores were: $0.0015 ; 0.009$; not significant (NS); 0.03 , respectively. For group 2 vs. $3, P$ values for hind paw left/right and forepaw left/right pathology scores were: 0.0007; 0.0007; NS; NS, respectively. An inflammation score above 2 was not recorded throughout the observation period

Table III. Adoptive Transfer of Suppression of CIA in the Mouse: Gross Pathology*

\begin{tabular}{|c|c|c|c|c|c|c|c|c|}
\hline \multirow[b]{4}{*}{ Group } & \multirow[b]{4}{*}{$\begin{array}{l}\text { Preinoculation } \\
\text { (i.v.) } \ddagger\end{array}$} & \multirow[b]{4}{*}{ Cells transferred§ } & \multirow[b]{4}{*}{$\begin{array}{l}\text { Incidence of } \\
\text { inflammation" }\end{array}$} & \multicolumn{5}{|c|}{ Pathology score } \\
\hline & & & & \multicolumn{4}{|c|}{ InflammationI } & \multirow[b]{3}{*}{$\begin{array}{l}\text { Digits } \\
\text { involved** }\end{array}$} \\
\hline & & & & \multicolumn{2}{|c|}{ Hind paw } & \multicolumn{2}{|c|}{ Forepaw } & \\
\hline & & & & Left & Right & Left & Right & \\
\hline & & & & & & & & $n$ \\
\hline 1 & Saline & $1 \times 10^{7}$ whole spleen & $10 / 11$ & 2.3 & 1.7 & 0.9 & 1.9 & 1.1 \\
\hline 2 & Native type I $\ddagger$ & $1 \times 10^{7}$ whole spleen & $8 / 8$ & 2.3 & 1.9 & 0.5 & 1.3 & 1.0 \\
\hline 3 & Native type IIfł & $1 \times 10^{7}$ whole spleen & $5 / 16$ & 0.7 & 0.8 & 0.4 & 0.7 & 0.1 \\
\hline 4 & Native type IIł‡ & $5 \times 10^{5}$ whole spleen & $7 / 9$ & 1.7 & 1.1 & 0.7 & 1.2 & 1.0 \\
\hline 5 & Saline & $1 \times 10^{7} \mathrm{~B}$ cells $\S$ & $7 / 9$ & 1.4 & 2.0 & 0.8 & 1.0 & 0.9 \\
\hline 6 & Native type II $\ddagger \ddagger$ & $1 \times 10^{7} \mathrm{~B}$ cells & $13 / 13$ & 1.9 & 1.4 & 0.6 & 1.3 & 1.1 \\
\hline 7 & Native type II $\ddagger$ & $1 \times 10^{7}$ thymocytes & $3 / 15$ & 0.9 & 0.9 & 0.3 & 0.4 & 0.4 \\
\hline
\end{tabular}

* Animal paws individually scored for arthritis on a scale of 1-5 based on the amount of erythema and edema, distortion, or ankylosis of the joint. ¥ Mice administered intravenous injection $3 \mathrm{~d}$ prior to sacrifice. Spleen was subsequently removed, minced into a single cell suspension, and adoptively transferred via tail vein. §Quantity and population of cells adoptively transferred via the tail vein $4 \mathrm{~d}$ before immunization with native type II collagen emulsified in CFA. Day of initial immunization was designated day 0 . "Number of animals with a recorded pathology score $>1$ by day 50 divided by the total number of mice per group at day 50 . I Average pathology score for the individual paw of

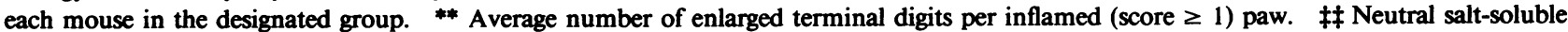
collagen isolated and purified as described in the text. $\$ \S$ Single cell suspensions of splenic cells treated with $\alpha$ Thy 1.2 and complement to remove functional $\mathrm{T}$ cells. Less than $5 \%$ of the B cells recovered by this procedure could be killed by a second treament of anti-Thy 1.2 plus complement. 
(day 20-50) for the animals in group 3. In addition, these animals were observed to have very limited enlargement of terminal digits on the mildly inflamed paws.

The observed adoptive transfer of suppression of collageninduced arthritis by whole spleen cell populations derived from animals that were preinoculated with native type II collagen was noted to be dependent on the number of cells transferred via the tail vein. As shown in Table III (group 4), 500,000 whole spleen cells adoptively transferred from native type II preinoculated-mice to naive animals resulted in the observation of collagen-induced arthritis in seven of nine mice tested. The individual inflammation pathology score ranged from 0 to 3 , indicating a moderate inflammation particularly apparent in the left hind paw and right forepaw. The observed pathology scores for these animals were not observed to be statistically significant compared to the arthritic pathology scores observed for the animals from groups 1 and 2 in Table III. In addition, the animals averaged at least one enlarged terminal digit per inflamed paw.

Groups 5 and 6 in Table III utilized subpopulations of splenic cells to determine the cell lineage capable of immunosuppression of CIA. Splenic single cell suspensions, depleted of functional T cells by treatment with $\alpha$ Thy 1.2 and complement, were adoptively transferred via the tail vein to naive animals. These B cell populations derived from mice preinoculated with saline or native type II collagen were unable to suppress CIA. The incidence of inflammation for group 5 was $78 \%$ or seven of nine animals positive for erythema and palpable edema. The incidence of inflammation for animals receiving $B$ cell preparations from animals preinoculated with native type II collagen was $100 \%$ ( 13 positive of 13 animals). The observed inflammation pathology scores for the animals in these groups were consistent with the values obtained for the animals in the control saline group (group 1 in Table III). On the other hand, the adoptive transfer of $1 \times 10^{7}$ thymocytes derived from mice preinoculated with native type II collagen (Table III, group 7) resulted in a significantly reduced incidence of inflammation ( $20 \%, 3$ of 15 animals positive for erythema and palpable edema) and severity of paw inflammation observed in CIA. For group 1 vs. $7, P$ values for hind paw left/right and forepaw left/right pathology scores were $P 0.005 ; 0.10$; NS; 0.003 . These data taken together indicate that Thy 1bearing $\mathrm{T}$ cells are necessary for immunosuppression of CIA.

Further studies utilizing radiolabeled native type II collagen administered intravenously prior to adoptive transfer ruled out antigen carry-over during cell transfer as the mechanism of suppression. Although $1 \%$ of the administered radioactivity was observed in the spleen, $<0.01 \%$ of administered radiolabel was noted in the single cell suspension of the splenic cells before injection.

Fig. 1, top panels, illustrates the hind paws of normal, arthritic (adoptively transferred spleen cells from saline-treated mice), and suppressed animals (adoptively transferred spleen cells from type II collagen-treated mice). Fig. 1, bottom panels, displays the forepaw from animals of the identical groups: normal, arthritic, and immunosuppressed.

Immune response to type II collagen. The immune response to native and denatured type II collagen was analyzed in the chronic arthritic-suppressed and arthritic mice utilized in the adoptive transfer experiments. A summary of the in vitro cellmediated immune responses to native and denatured type II collagen of these animals is presented in Table IV. The data for two groups presented (arthritic and suppressed) are reflective of the respective seven groups analyzed and presented in Table III. In the CIA group (Table IV, group 1), in which spleen cells from animals preinoculated with saline were adoptively transferred, cell-mediated immune responses to native and denatured collagen were observed (SI: $4.0 \pm 1.6$ and 3.0 \pm 0.8 , respectively). These in vitro immune responses to native and denatured collagen were abrogated by treatment of the cells with $\alpha$ Thy 1.2 and complement $(P$ values $<0.01$ and $<0.01$, respectively). Suppressed $(P<0.01)$ cellular responses to native type II collagen with concomitant similar cellular responses to denatured type II collagen were observed for the immunotherapeutically suppressed group (Table IV, group 2). These animals, which were recipients of $1 \times 10^{7}$ whole spleen cells from mice administered $500 \mu \mathrm{g}$ of native type II collagen intravenously, displayed in vitro immune response to both native and denatured collagens which was abrogated by treatment of the cells with $\alpha$ Thy 1.2 and complement ( $P$ values $<0.01$ and $<0.001$, respectively). These data indicate that the cellular subpopulation reactive to type II collagen in vitro are of $\mathrm{T}$ cell origin.

Cell depletion studies that utilized antisera to lymphocyte surface antigens $L y 1$ and Ly2 and complement were performed to determine the phenotype of the functional $\mathrm{T}$ lymphocyte populations responding to native and denatured collagen. Examination of the functional roles of $\mathrm{T}$ lymphocytes expressing the Lyl and Ly2 surface antigens has shown that splenic cells can be separated into two functional populations; $\mathrm{Ly}^{+} 2^{-} \mathrm{T}$ helper/inducer cells, and $\mathrm{Ly}^{-} 2^{+}$, cytotoxic/suppressor cells. By utilizing the anti-Ly antisera and complement with the splenic cells responding to type II collagen, it was observed that treatment of the cells from the immunosuppressed CIA group with anti-Ly2 and complement abrogated the response to native and denatured type II collagen ( $P$ values for cultures incubated with either native or denatured collagen, $P<0.001$ ). This abrogation with Ly2 antisera was not observed in CIA animals, group I. It can be noted that anti-Lyl and complement reduced the cellular responses to a nonstimulating level in the collagen-induced arthritis animals $(P<0.05)$, indicating the generation of collagen $T$ helper/inducer cells. However, reduction of in vitro immune responses to nonstimulatory levels in cultures containing splenic cells derived from arthritically suppressed mice was not observed with incubation with $\alpha \mathrm{Ly}-1$ and complement. Therefore, the $\mathrm{T}$ cells (Thyl bearing) observed in vitro in chronic arthritic-suppressed mice portray the $\mathrm{Ly}^{-} 2^{+}$phenotype. These latter splenic cells, which can be generated by intravenous injection of native type II collagen and reduce the erythema and edema observed in CIA, are phenotypically $\mathrm{T}$ suppressor cells.

Analysis of the serum anti-collagen antibodies of the recipient mice showed that arthritic mice expressing $\mathrm{Ly} 1^{+} 2^{-}$splenic helper/inducer $\mathrm{T}$ cells contained relatively high serum concentrations of antibodies to native and denatured type II collagen. On the other hand, chronic arthritic-suppressed mice, expressing Ly $1^{-} 2^{+}$splenic suppressor/cytotoxic $T$ cells, had suppressed level of serum antibodies to type II collagen. These two groups of recipient mice, arthritic and suppressed, are represented in Table IV by groups 1 and 2, respectively. As shown in Table IV, arthritic (group 1) mice displayed average serum concentrations of $7.3 \pm 1.3 \mathrm{mg} / \mathrm{ml}$ anti-native type II collagen antibodies and $1.3 \pm 0.2 \mathrm{mg} / \mathrm{ml}$ anti- $\alpha 1$ (II) antibodies. These values are significantly elevated $(P<0.005)$ compared with the recipientsuppressed group 2 . The average serum concentrations for these animals were $2.6 \pm 0.2$ and $0.5 \pm 0.1 \mathrm{mg} / \mathrm{ml}$, respectively. 

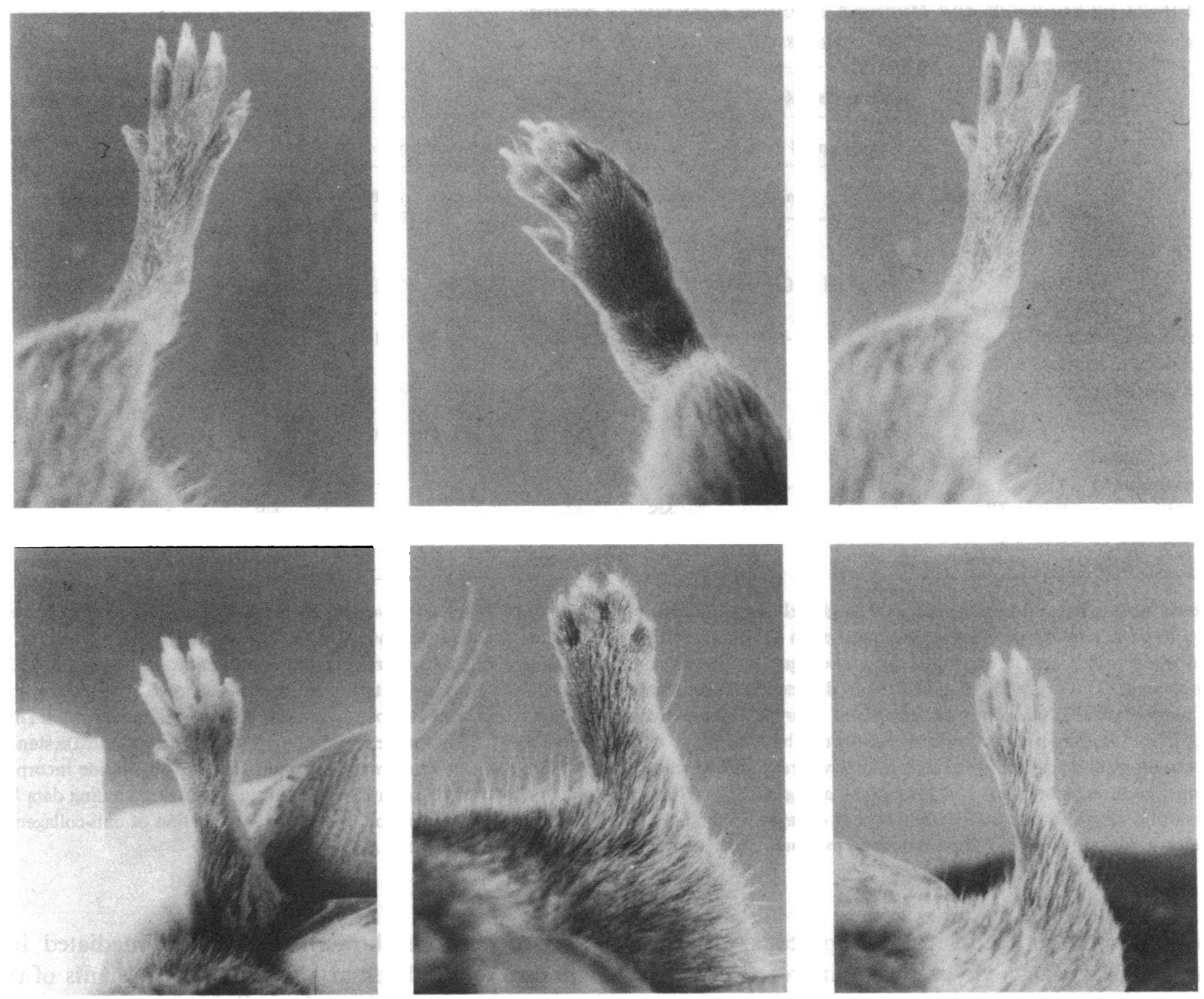

Figure 1. (Top left) Hind paw of a normal DBA/1J mouse randomly chosen from stock. (Top middle) Hind paw of a DBA/1J mouse with adoptively transferred $1 \times 10^{7}$ normal spleen cells and subsequently immunized twice with native type II collagen emulsified in CFA. The paw was scored 4 on a scale of 1-5 and represents a period of $50 \mathrm{~d}$ after initial injection of type II collagen/CFA. (Top right) Hind paw of a age-matched DBA/1J mouse with adoptively transferred $1 \times 10^{7}$ spleen cells derived from mice previously administered $500 \mu \mathrm{g}$ of soluble native type II collagen. After cellular transfer the mouse was immunized twice with native type II collagen emulsified in CFA. The paw was scored 0 and represents a period of $50 \mathrm{~d}$ after initial injection of type II collagen/CFA. (Bottom left) Forepaw of a normal

It can be noted that, in recipient mice receiving $1 \times 10^{7}$ thymocytes from native type II collagen preinoculated mice (group 7 in Table III), the serum titers of antibodies to native and denatured type II collagen were virtually absent at $0.019 \pm 0.03$ and $0.078 \pm 0.04 \mathrm{mg} / \mathrm{ml}$, respectively. These data could reflect the relative suppressive function of splenic vs. thymic $\mathrm{T}$ cells or, alternatively, represent the limited expression of "nonpathological" anti-type II collagen antibodies in chronic arthritically suppressed mice.

\section{Discussion}

This study details the initial observation of type II collagenspecific $T$ suppressor cells functionally capable of suppressing the erythema and edema of CIA in the mouse. These cells are generated on intravenous inoculation of soluble native type II collagen before immunization with smaller amounts of native type II collagen emulsified in CFA. The type II collagenspecific $\mathrm{T}$ suppressor cells or their precursors are evident in
DBA/1J mouse randomly chosen from stock. (Bottom middle) Forepaw of a DBA/1J mouse with adoptively transferred $1 \times 10^{7}$ normal spleen cells and subsequently. immunized twice with native type II collagen emulsified in CFA. The paw was scored 5 on a scale of 1-5 and represents a period of $50 \mathrm{~d}$ after initial injection of type II collagen/CFA. (Bottom right) Forepaw of a age-matched DBA/1J mouse with adoptively transferred $1 \times 10^{7}$ spleen cells derived from mice previously administered $500 \mu \mathrm{g}$ of soluble native type II collagen. After cellular transfer the mouse was immunized twice with native type II collagen emulsified in CFA. The paw was scored 1 and represents a period of $50 \mathrm{~d}$ after initial injection of type II collagen/ CFA.

the spleen and thymus as early as $3 \mathrm{~d}$ after intravenous inoculation as demonstrated by adoptive transfer experiments. These cells are also specific for epitope(s) on type II collagen molecules, inasmuch as intravenous inoculation of identical quantities of native type I collagen proved to be nonsuppressive. These latter findings are consistent with the antigen-specific suppression of CIA in the rat (9). Also, the present data indicate that type II collagen-specific $\mathrm{T}$ suppressor cells are not generated in splenic populations adoptively transferred subsequent to intravenous injections of type I collagen.

In addition to suppression of the erythema and edema observed in CIA, the type II-specific suppressor cells influenced the cell-mediated and humoral immune response to type II collagen. With regard to cell-mediated immune responses to type II collagen, in vitro cellular responses to native and denatured collagen were observed in collagen-induced arthritic mice. Cellular responses to native type II collagen appear to be more vigorous and consistent than responses to the $\alpha 1$ (II) polypeptide chain and, particularly in the case of adoptive 
Table IV. In Vitro Cell-mediated and Humoral Immune Response to Native and Denatured Type II Collagen in Immunosuppressed and Arthritic Mice

\begin{tabular}{|c|c|c|c|c|c|c|c|c|c|c|c|c|}
\hline \multirow[b]{3}{*}{ Group } & \multirow{3}{*}{$\begin{array}{l}\text { Preinoculation } \\
\text { (i.v. })^{*}\end{array}$} & \multirow[b]{3}{*}{ Cells transferred } & \multicolumn{8}{|c|}{ Cell mediated§ } & \multicolumn{2}{|l|}{ Humoral" } \\
\hline & & & \multicolumn{4}{|c|}{ Native type II collagen } & \multicolumn{4}{|c|}{ Denatured type II collagen } & \multirow{2}{*}{$\begin{array}{l}\text { Native } \\
\text { type II } \\
\text { collagen }\end{array}$} & \multirow{2}{*}{$\begin{array}{l}\text { Denatured } \\
\text { type II } \\
\text { collagen }\end{array}$} \\
\hline & & & Diluent & $\alpha$ Thy 1 & $\alpha$ Lyl & $\alpha \operatorname{Ly} 2$ & Diluent & $\alpha$ Thy 1 & $\alpha$ Lyl & $\alpha \operatorname{Ly} 2$ & & \\
\hline & & & & & & & & & & & \multicolumn{2}{|c|}{$m g / m l$} \\
\hline 1 & $\begin{array}{l}\text { Saline } \\
P \text { value; diluent vs. } \\
P \text { value; diluent vs. } \\
P \text { value; diluent vs. }\end{array}$ & $\begin{array}{l}1 \times 10^{7} \\
\text { whole spleen } \\
\alpha \text { Thy } 1.2+C^{\prime} \\
\alpha \text { Ly1 }+C^{\prime} \\
\alpha \text { Ly2 }+C^{\prime}\end{array}$ & $4.0 \pm 1.6 \pi$ & $\begin{array}{c}0.9 \pm 0.4 \\
\vdots \\
<0.01\end{array}$ & $\begin{array}{c}1.5 \pm 0.7 \\
\vdots \\
<0.05\end{array}$ & $\begin{array}{c}3.9 \pm 0.5 \\
\vdots \\
\vdots \\
\text { NS }\end{array}$ & $3.0 \pm 0.8$ & $\begin{array}{c}1.1 \pm 0.3 \\
<0.01\end{array}$ & $\begin{array}{c}0.5 \pm 0.1 \\
\vdots \\
<0.01\end{array}$ & $\begin{array}{c}1.8 \pm 1.0 \\
\vdots \\
\vdots \\
\text { NS }\end{array}$ & $7.3 \pm 1.3^{* *}$ & $1.3 \pm 0.2$ \\
\hline 2 & $\begin{array}{l}\text { Native } \\
\quad \text { type II collagen } \\
P \text { value; diluent vs. } \\
P \text { value; diluent vs. } \\
P \text { value; diluent vs. }\end{array}$ & $\begin{array}{l}1 \times 10^{7} \\
\text { whole spleen } \\
\alpha \text { Thy } 1.2+C^{\prime} \\
\alpha \text { Ly1 }+C^{\prime} \\
\alpha \text { Ly2 }+C^{\prime}\end{array}$ & $2.1 \pm 0.4$ & $\begin{array}{c}1.1 \pm 0.2 \\
\vdots \\
<0.01\end{array}$ & $\begin{array}{c}1.7 \pm 0.4 \\
\vdots \\
\dot{\mathrm{NS}}\end{array}$ & $\begin{array}{c}0.9 \pm 0.2 \\
\vdots \\
\vdots \\
<0.001\end{array}$ & $4.0 \pm 0.4$ & $\begin{array}{c}1.0 \pm 0.3 \\
\vdots \\
<0.001\end{array}$ & $\begin{array}{c}5.3 \pm 0.4 \\
\vdots \\
\text { NS }\end{array}$ & $\begin{array}{c}1.0 \pm 0.1 \\
\vdots \\
\vdots \\
<0.001\end{array}$ & $2.6 \pm 0.2$ & $0.5 \pm 0.1$ \\
\hline
\end{tabular}

\begin{abstract}
* Mice administered inoculation $3 \mathrm{~d}$ before killing. ‡ Single cell suspensions adoptive transferred via the tail vein to naive mice. The animals were subsequently immunized with $100 \mu \mathrm{g}$ of native type II collagen emulsified in CFA. § In vitro cell-mediated immune response of pooled splenic cell derived from the designated group before incubation with native or denatured type II collagen, single cell suspensions were aliquoted and treated with either saline, anti-Ly1, anti-Ly2, or antiThy 1.2 and complement. This procedure was utilized to deplete the whole spleen population of the appropriate functional cell(s) lineage. The average number of cells determined to be functionally depleted as determined by trypan blue exclusion after treatment with the specific antisera and complement were $\alpha$ Thy $1,37 \%$; $\alpha \mathrm{Ly} 1,22 \% ; \alpha \mathrm{Ly} 2,7 \%$. "Antibody concentrations determined by solid-phase radioimmunoassay. I Values presented as an SI (defined in the text) \pm standard deviation. Antigen incubated wells were performed in triplicate whereas saline incubated wells were replicated minimally six times. The $\left[{ }^{3} \mathrm{H}\right]$ thymidine incorporation levels of the nonstimulated cultures were group $1,4,311 \pm 1,023$; and group $2,4,871 \pm 2,725$. ** Concentrations of antibody determined utilizing binding data from samples of known concentration of specifically purified anti-type II collagen antibodies (see text). The observed reduction in serum concentration of anti-collagen antibodies directed to native or denatured type II collagen observed in group 2 recipient mice is statistically significant at $P<0.005$.
\end{abstract}

transfer, were observed to be relatively suppressed. In this regard, suppressed delayed-type hypersensitivity reactions have been previously reported $(8,11)$ in rats made tolerant of CIA. This suppression of cell-mediated values could, however, represent a difference in proliferative rates of suppressor vs. helper cells or, alternatively, could reflect the synergistic heterogeneous activity of a population antigen-specific $T$ helper cells $(21,22)$. These observed cell-mediated immune responses could be abrogated by treatment of the cellular suspensions with $\alpha$ Thy 1 plus complement. These observations represent values obtained in the chronic phase of CIA.

In a previously reported study (3), cell-mediated immune responses predominantly to denatured type II collagen with declining cell-mediated responses to both native and denatured type II collagen in the chronic phase of CIA have been noted. These data are not consistent with the present data and may reflect the varying culture conditions and pulse time or modulations of the immune response to collagen over the time course of CIA. It is more likely, however, that this discrepancy is due to the utilization of adjuvant in the present study for the induction of CIA. Such methodology would allow for sustained retention of the immunogen in situ and sustained chronic cell-mediated immune responses to collagen. To this point, it is unknown whether the presently reported cell-mediated immune responses represent sustained stable cell-mediated responses or reflect declining responses in chronic CIA.

Present studies detailing the adoptive transfer of suppression of CIA in the murine model of CIA indicated that cellmediated immune responses to native type II collagen were reduced in mice preinoculated with type II collagen compared with the CIA group. Cell-mediated immune responses to the $\alpha 1$ (II) polypeptides were comparable, however, in each group. Additional studies that utilized specific antisera to lymphocyte surface antigens showed that the cell-mediated immune responses to the different antigenic determinants of the collagen molecule were derived from the same $T$ cell subpopulation and that different $T$ cell subpopulations were responding in CIA mice and mice suppressed for CIA. The cellular population of $\mathrm{T}$ cells in chronic, arthritically suppressed mice responding to in vitro incubation of native or denatured type II collagen were phenotypically $\mathrm{Ly}^{-} 2^{+}$. In addition, no significant $\mathrm{Lyl}^{+}$ responses were observed in cultures derived from the arthritically suppressed mice. On the other hand, the cellular population of $T$ cells responding to native or denatured collagen in the arthritic type II group was phenotypically $\mathrm{Ly} \mathrm{I}^{+}$cells. These data indicate that two phenotypically distinct $T$ cell subgroups can be generated in response to inoculation with native type II collagen. Therefore, type II collagen-induced T suppressor cells are observed in immunotherapeutically suppressed mice whereas the splenic cell-mediated immune response in collageninduced arthritic mice is composed of T-helper/inducer cells. The observation of collagen-specific $T$ helper cells has previously been reported (23) and the role of $\mathrm{T}$ helper cells in initiation and maintenance of arthritis is under investigation (24).

With regard to the humoral immune response to type II collagen, arthritic mice displaying $\mathrm{Ly} 1^{+} 2^{-}$splenic helper/inducer $T$ cells were observed to contain relatively high serum concentrations of antibodies to both native and denatured type II collagen. However, mice suppressed with regard to the erythema and edema observed with CIA and expressing Ly $1^{-} 2^{+}$splenic suppressed/cytotoxic cells had comparatively lower serum concentrations of antibodies to native and denatured collagen. These data could reflect the expression of anti-collagen antibodies below a pathological level representing a threshold phenomena required for expression of CIA. Alternatively, antibody populations expressed in arthritically suppressed animals could represent a restricted expression of nonpathological 
antibodies, that is, for instance, antibodies comprised of a subclass that does not bind complement effectively. In addition, these animals could reflect a release from the suppressed state and the antibodies could be representative of early immunologic events of CIA. Further studies are required to establish the nature of these antibodies to type II collagen.

The immune response to type II collagen in CIA mice and CIA-suppressed mice can be summarized as follows. The generation of $\mathrm{T}$ suppressor cell in CIA-suppressed mice results in cell-mediated immune responses of the $\mathrm{Ly}^{-} 2^{+}$phenotype with concomitant suppressed (nonobserved) $\mathrm{Lyl}^{+} 2^{-}$responses and serum anti-collagen antibody concentrations. On the other hand, CIA mice do not display $\mathrm{Lyl}^{-} 2^{+} \mathrm{T}$ cell responses, but are observed to have $\mathrm{Lyl}^{+} 2^{-} \mathrm{T}$ cell responses and comparatively high serum anti-type II collagen antibodies.

The generation of suppressor $\mathrm{T}$ cells in mice treated with a single large dose of antigen was first demonstrated by Gershon and Kondo (25) and was termed infectious tolerance. In these studies, $T$ cells were observed to transfer unresponsiveness to sheep erythrocytes in naive animals. In numerous other experimental systems (26-28), where immunologic tolerance was induced by administration of high doses of soluble antigen, antigen-specific suppressor $\mathrm{T}$ cells have been identified. From these and other studies (29-31), regulatory circuits composed of $T$ cells expressing characteristic surface markers associated with genetically determined function have been described. The circuits are composed of inducer $T$ cells of

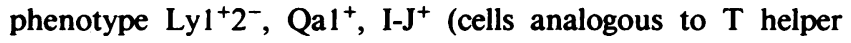
cells with regard to Lyl phenotype; however, recent fluorometric studies have indicated that Lyl is present in most, if not all, $T$ lymphocytes $(32,33)$ with low density Ly $1 \mathrm{~T}$ cells previously designated $\mathrm{Ly}^{-}$). These $\mathrm{Ly} 1^{+}$helper/inducer cells modulate the expression of $\mathrm{Lyl}^{+} 2^{+}, 1-\mathrm{J}^{+}, \mathrm{Qa} 1^{+}$cells, which differentiate or activate $\mathrm{Ly}^{-} 2^{+}{\mathrm{I}-\mathrm{J}^{+}}^{+}$effector/suppressor cells. The latter cells may inhibit the function of $\mathrm{Ly}^{+}$helper cells and $\mathrm{Ly}^{+}$inducer cells. These $\mathrm{Ly}^{-} 2^{+}$efferent suppressor cells are the population of $\mathrm{T}$ cells presently identified in chronically (day 50) suppressed collagen-induced arthritic mice. Such regulatory effector cells are postulated to secrete antigenspecific suppressor factors (34-38), which mediate the suppressive effects of these cells. Present ongoing studies are investigating the nature of collagen-specific suppressor factors.

Numerous studies have been undertaken to establish the factors that determine whether the administration of antigen leads to a state of unresponsiveness or a primary immune response. It is apparent that prominent factors influencing the host response are the dose of antigen, physiochemical properties of the antigen, and presentation of antigen. With regard to route of antigen presentation, extensive studies indicate that avenues that avoid immunization tend to favor tolerance induction. Presentation of antigen intradermally induces contact sensitivity whereas intravenous injection of antigen results in tolerance $(39,40)$. Studies utilizing doses of antigen greater than the usual immunizing range have shown that these conditions generally tend to induce unresponsiveness to antigen (41-43). As a general rule, these studies indicate that the larger the dose the greater degree of unresponsiveness and the longer its duration. Cell-transfer experiments (44) have shown that high-dose tolerance reflects unresponsiveness of both $T$ helper cells $\left(\mathrm{Ly} 1^{+} 2^{-}\right)$and $\mathrm{B}$ cells. Induction of a state of tolerance is also dependent on the time of presentation before or after antigenic challenge (9). Investigations using extensive periods of time before or after challenge have reported difficulty in inducing tolerance $(46,47)$. A final factor, the physical properties of antigens can influence the capacity to induce immunity or unresponsiveness. Dresser $(43,45)$ has shown a differential effect for soluble protein fraction in comparison to aggregated fractions in the induction of a state of unresponsiveness.

The induction and maintenance of tolerance to type II collagen can be relevant immunotherapeutically to certain forms of arthritis. The association of both humoral and cellmediated immune responses to the genetically distinct interstitial collagens, in particular, type II collagen in patients with rheumatoid arthritis (48) and the observation of mammalian CIA $(49,50)$ suggests that antigen-specific suppression of the immune response to collagen could be utilized to abrogate arthritis.

Note added in proof. The authors acknowledge a recent publication (Wooley, P. H., H. S. Luthra, C. J. Krco, J. M. Stuart, and C. S. David. 1984. Type II collagen-induced arthritis in mice. II. Passive transfer and suppression by intravenous injection of anti-type II collagen antibody or free native type II collagen. Arthritis Rheum. 27: 1010-1017) showing, in part, the antigen-specific suppression of collagen arthritis in the mouse.

\section{Acknowledgments}

The authors thank Candace Finegan for her excellent technical assistance and Terri Grenwis-Woodcraft for her typing of the manuscript.

This work was supported by grant AM-30134 from the U. S. Public Health Service and the Revco Drug Store Research Foundation.

\section{References}

1. Trentham, D. E., A. S. Townes, and A. H. Kang. 1977. Autoimmunity to type II collagen: an experimental model of arthritis. J. Exp. Med. 146:857-868.

2. Courtenay, J. S., M. J. Dallman, A. D. Dayad, A. Martin, and B. Mosedale. 1980. Immunization against heterologuous type II collageninduced arthritis in mice. Nature (Lond.). 283:666-668.

3. Stuart, J. M., A. S. Townes, and A. H. Kang. 1982. Nature and specificity of the immune response to collagen in type II collageninduced arthritis in mice. J. Clin. Invest. 69:673-683.

4. Trentham, D. E., A. S. Townes, and A. H. Kang. 1978. Humoral and cellular sensitivity to collagen in type II collagen-induced arthritis in rats. J. Clin. Invest. 61:89-96.

5. Trentham, D. E., R. A. Dynesius, and J. R. David. 1978. Passive transfer by cells of type II collagen-induced arthritis in rats. J. Clin. Invest. 61:359-366.

6. Stuart, J. M., M. A. Cremer, A. S. Townes, and A. H. Kang. 1982. Type II collagen-induced arthritis in rats. Passive transfer with serum and evidence that IgG anti-collagen antibodies can cause arthritis. J. Exp. Med. 155:1-16.

7. Staines, N. A., T. Hardinghma, M. Smith, and B. Henderson. 1981. Collagen-induced arthritis in the rat: modification of immune and arthritic responses by free collagen and immune anti-collagen antiserum. Immunology. 44:737-744.

8. Schoen, R. T., M. I. Greene, and D. E. Trentham. 1982. Antigen specific suppression of Type II collagen-induced arthritis by collagencoupled spleen cells. J. Immunol. 128:717-719.

9. Cremer, M. A., A. D. Hernandez, A. S. Townes, J. M. Stuart, and A. H. Kang. 1983. Collagen-induced arthritis in rats: antigen specific suppression of arthritis and immunity by intravenously injected native type II collagen. J. Immunol. 131:2995-3000.

10. Englert, M. E., M. J. Landes, A. L. Oronsky, and S. S. Kerwak. 1984. Suppression of type II collagen-induced arthritis by the intravenous administration of type II collagen or its constituent peptide $\alpha$ l(II) CB10. Cell. Immunol. 87:357-365.

11. Brahn, E., and D. E. Trentham. 1984. Antigen-specific suppres- 
sion of collagen arthritis by adoptive transfer of spleen cells. Clin. Immunol. Immunopathol. 31:124-131.

12. Kresina, T. F., I. A. Rosner, V. M. Goldberg, B. A. Boja, and R. W. Moskowitz. 1984. IgG-induced experimental immune syunovitis: hormonal modulation of in vitro splenic immune responses to homologous antigen. Clin. Exp. Immunol. 57:63-72.

13. Trelstad, R. C., V. M. Catanese, and C. F. Rubin. 1976. Collagen fractionation: separations of native types I, II and III by differential precipitation. Anal. Biochem. 17:114-118.

14. Kresina, T. F., and E. J. Miller. 1979. Isolation and characterization of basement membrane collagen from human placental tissue: evidence for the presence of two genetically distinct collagen chains. Biochemistry. 18:3089-3097.

15. Gay, S., and E. J. Miller. 1979. Characterization of lens capsule collagen: evidence for the presence of two unique chains in molecules derived from major basement membrane structures. Arch. Biochem. Biophys. 198:370-378.

16. Kresina, T. F., and C. J. Malemud. 1984. Susceptibility of interstitial rabbit collagen to rabbit articular chondrocyte collagenase. Collagen Relat. Res. 4:453-465.

17. Kresina, T. F., I. A. Rosner, V. M. Goldberg, and R. W. Moskowitz. 1984. Experimental immunoglobulin G-induced chronic immune synovitis: cell-mediated immunity to native interstitial collagen molecules and their constituent polypeptide chains. Cell. Immunol. 87:504-516.

18. Gosslau, B., and H. J. Barrach. 1979. Enzyme-linked immunosorbent microassay for quantification of specific antibodies to collagen types I, II, III. J. Immunol. Methods. 29:71-77.

19. Kresina, T. F., I. A. Rosner, V. M. Goldberg, and R. W. Moskowitz. 1985. Fine specificity of serum anti-collagen molecules in experimental immune synovitis. Ann. Rheum. Dis. In press.

20. Stuart, J. M., K. Tomada, T. J. Yoo, A. Townes, and A. H. Kang. 1983. Serum transfer of collagen-induced arthritis II. Identification and localization of autoantibody to type II collagen in donor and recipient rats. Arthritis Rheum. 26:1237-1244.

21. Tada, T., T. Takemori, K. Okumura, M. Nonaka, and T. Tokuhisa. 1978. Two distinct types of helper $T$ cells involved in the secondary antibody response. Independent and synergistic effects of $\mathrm{Ia}^{-}$and $\mathrm{Ia}^{+}$helper T cells. J. Exp. Med. 147:446-458.

22. Janeway, C. A., D. L. Bert, and F. W. Shen. 1980. Cell cooperation during in vivo anti-hapten antibody responses. V. Two synergistic Lyl ${ }^{+} 23^{-} \mathrm{T}$ cells with distinctive specificities. Eur. J. Immunol. 10:231-236.

23. Hom, J. T., J. M. Stuart, J. M. Chiller, and A. H. Kang. 1984. Characterization of murine T-cell lines end-clones reactive to Type II collagen. Fed. Proc. 43:1908. (Abstr.)

24. Klareskog, L., U. Forsum, A. Scheynius, D. Kabelitz, and H. Wigzell. 1982. Evidence in support of a self-perpetuating HLA-DRdependent delayed-type cell reaction in rheumatoid arthritis. Proc. Natl. Acad. Sci. USA. 79:3632-3639.

25. Gershon, R. K., and K. Kondo. 1972. Infectious immunological tolerance. Immunology. 21:903-914.

26. Nachtigal, D., I. Zan-Bar, and M. Feldmann. 1975. The role of specific suppressor $\mathrm{T}$ cells in immune tolerance. Transplant. Rev. 26:87-105.

27. Basten, A., J. F. A. Miller, J. Sprent, and C. Cheers. 1974. Cell-to-cell interaction in the immune response $x$. T-cell dependent suppression in tolerant mice. J. Exp. Med. 140:199-217.

28. Benjamin, D. C. 1975. Evidence for specific suppression in the maintenance of immunological tolerance. J. Exp. Med. 141:635-646.

29. Eardly, D. D., J. Hugenberger, L. McVay-Boudreau, F. W. Shen, R. K. Gershon, and H. Cantor. 1978. Immunoregulatory circuits among T-cell sets. I. T-helper cells induce other T-cell sets to exert feedback inhibition. J. Exp. Med. 147:1105-1115.
30. Eardly, D. D., D. B. Murphy, J. D. Kemp, F. W. Shen, H. Cantor, and R. K. Gershon. 1980. Ly-1 inducer and Ly-1,2 acceptor $\mathrm{T}$ cells in the feedback suppression circuit bear an I-J subregion controlled determinant. Immunogenetics. 11:549-557.

31. Dorf, M. E., and B. Benacerraf. 1984. Suppressor cells and immunoregulation. Annu. Rev. Immunol. 2:127-158.

32. Ledbetter, J. A., R. V. Rouse, S. Micklem, and L. A. Herzenberg. 1980. T cell subsets defined by expression of $L y-1,2,3$ and Thy-1 antigens. Two parameter immunofluorescence and cytotoxicity analysis modifies current views. J. Exp. Med. 152:280-295.

33. Potter, T. A., P. M. Hogarth, and I. F. C. McKenzie. 1980. Flow microfluorometric analysis of alloantigen expression during $T$ cell development. Eur. J. Immunol. 10:899-903.

34. Tada, T., M. Toniguchi, and K. Okumura. 1977. Regulation of antibody response by antigen-specific $\mathrm{T}$ cell factors bearing $\mathrm{I}$ region determinants. Prog. Immunol. 3:369-377.

35. Taniguchi, M., and T. Tokuhisa. 1980. Cellular consequences in the suppression of antibody response by the antigen specific T-cell factor. J. Exp. Med. 151:517-527.

36. Yamauchi, K., D. Murphy, H. Cantor, and R. K. Gershon. 1981. Analysis of antigen-specific, Ig restricted cell free material made by $1-2^{+}$Ly-1 cells (Ly-1, Tsi F) that induces $\mathrm{Ly}-2^{+}$cells to express suppressor activity. Eur. J. Immunol. 11:905-912.

37. Yamauchi, K., D. Murphy, H. Cantor, and R. K. Gershon. 1981. Analysis of an antigen-specific H-2 restricted cell-free product(s) made by I-J $L y-2$ cells $(L y-2, T s F)$ that suppress $L y-2$ cell-depleted spleen cell activity. Eur. J. Immunol. 11:913-918.

38. Kontianinen, S., and M. Feldman. 1977. Suppressor cell function in vitro. III. Antigen specific suppression by supernatants of suppressor cells. Eur. J. Immunol. 7:310-314.

39. Mottram, P. L., and J. F. A. Miller. 1980. Delayed-type hypersensitivity induced by antigen-pulsed bone marrow-derived macrophages. Eur. J. Immunol. 10:165-170.

40. Ptak, W., D. Rozychka, P. W. Askenase, and R. K. Gershon. 1980. Role of antigen presenting cells in the development and persistence of contact sensitivity. J. Exp. Med. 151:362-375.

41. Dixon, F. J., and P. H. Maurer. 1955. Immunologic unresponsiveness induced by protein antigen. J. Exp. Med. 101:245-257.

42. Smith, R. T., and R. A. Bridges. 1983. Immunological unresponsiveness in rabbits produced by intravenous injection of defined antigens. J. Exp. Med. 108:227-250.

43. Dresser, D. W. 1962. Specific inhibition of antibody production I. Protein-overloading paralysis. Immunology. 5:161-168.

44. Weigle, W. O. 1971. Recent observations and concepts in immunological unresponsiveness and autoimmunity. Clin. Exp. Immunol. 9:437-447.

45. Dresser, D. W. 1965. Specific inhibition of antibody production. IV. standardization of the antigen elimination test: immunological paralysis of mice previously immunized. Immunology. 9:261-273.

46. Dorner, M. M., and J. W. Uhr. 1964. Immunological tolerance after specific immunization. J. Exp. Med. 120:435-444.

47. Nelson-Rampy, P. A., D. E. Parks, and W. O. Weigle. 1981. Establishment of unresponsiveness in primed B lymphocytes in vivo. J. Immunol. 127:1415-1422.

48. Stuart, J. M., A. S. Townes, and A. H. Kang. 1984. Collagen autoimmune arthritis. Annu. Rev. Immunol. 2:199-218.

49. Kang, A. H., T. J. Yoo, Y. Yazawa, D. Orchik, R. Floyd, G. Olson, N. Sudo, T. Ishibe, J. J. Shea, and T. Takeda. 1984. Induction of type II collagen autoimmune arthritis and ear disease in monkey. Fed. Proc. 43:1994. (Abstr.)

50. Cathcart, E. S., K. C. Hayes, W. Gonnerman, A. H. Lazzari, and C. Franzblau. 1984. Experimental arthritis in a nonhuman primate. Am. Fed. Clin. Res. 32:426A. (Abstr.) 